\title{
Youth, Future and Faith
}

\begin{abstract}
In Western countries, youth and faith don't seem to be close to each other. "Sixties Protests" might be seen as the starting point of this phenomenon, being the turning point that caused the youth averted from the Catholic Church. At the same time, it brought the need of the promotion of Christian education and the care about youth from the side of the Catholic Church. The article, under its educational proposal, reasons how important it is to help young people to discover the Christian faith as essential to their life, especially in order to become free and to look positively at the future. Faith and future are related closely one to the other. In fact, to become free doesn't necessarily mean to have possibility to choose from many options, we are free only when we choose good. This attitude involves the ability to preserve one's own life, but it is possible only if someone does not only take each day as it comes, but he or she can see their future in front. Christian faith is essential for a human, particularly young, in order to recognize that there is actually the future even if life is uncertain as it happens today, because the Christian God is "the one who is and who was and who is to come" (Revelation 1:8). For this reason, to believe in Jesus means to be motivated to preserve themselves.
\end{abstract}

KEY WORDS

youth, future, faith, education, pedagogy, freedom

\section{SLOWA KLUCZOWE}

młodzież, przyszłość, wiara, edukacja, pedagogika, wolność

SPI Vol. 19, 2016/4

ISSN 2450-5358

e-ISSN 2450-5366

D0I: 10.12775/SPI.2016.4.003

Articles and Dissertations 


\section{ABSTRAKT}

W krajach zachodnich młodzież i wiara nie wydaja się być blisko siebie. Poczq̨tów tego zjawiska należy dopatrywać się w „proteście lat sześćdziesiątych", przełomu który spowodował odwrócenie się wielu młodych ludzi od Kościoła katolickiego. Równocześnie wywołał on potrzebę promocji edukacji chrześcijańskiej i opieki nad młodzieżq ze strony Kościoła katolickiego. Niniejszy artykuł, w ramach edukacyjnej propozycji, uzasadnia jak ważne jest, aby pomagać młodym ludziom odkrywać wiarę chrześcijańskq, jako istotnq dla ich życia, przynoszqcq poczucie wolności oraz dającq możliwość pozytywnego patrzenia w przyszłość. Wiara i przyszłość bowiem wiq̨żq się ściśle ze sobq. W rzeczywistości, bycie wolnym nie oznacza możliwości wyboru spośród wielu opcji, jesteśmy wolni jedynie kiedy wybieramy dobro. Postawa ta polega na zdolności do zachowania własnego życia, ale jest to możliwe tylko wtedy, gdy kłoś nie żyje wyłącznie dniem dzisiejszym, lecz widzi przed sobq swoja przyszłość. Wiara chrześcijańska jest niezbędna, aby człowiek, zwłaszcza młody, dostrzegł, że istnieje przyszłość, nawet jeśli żyjemy w niepewności, jak to się dzieje dzisiaj, ponieważ Bóg chrześcijański to „Ten, który jest i który był, i który ma przyiść" (Ap 1,8). Z tego powodu wiara w Jezusa daje motywację do zachowania siebie samego.

Within Western countries, young people and faith are far from being close. In my opinion, the difficulties stem from the "Sixties Protests", a cultural turning-point related to the new leadership of young people within society and their strong criticism of traditions and institutions. Obviously, as the Christian faith is expressed by doctrinal beliefs and institutional Churches, the relationship became difficult. Furthermore, the role of young people within the Church and within society is only proportional as it is shared with believers who are no longer young. This is why the "Sixties Protests" involved a contradiction, leading them to be overcome today. In the light of what I said before I aim to face the issue concerning the relationship between young people and Christian faith positively. In fact, nowadays the situation is very different from the 1960s: uncertainty has replaced ideological certitudes; unemployment has replaced work opportunities; the economic crisis has replaced an affluent society; 
the fear about the future has replaced dreams about the future. I'm speaking from the point of view of Western countries (also those which are deep-rooted in Christian traditions like Italy), perhaps the situation is different elsewhere-like in Poland-but it seems to me that the general trend is the same everywhere. Today we have the opportunity to bring young people nearer to the faith because faith and the future are very close and young people find their future very hard to deal with. From the methodological point of view my argumentation will be based upon texts from the teachings of the Church and critical sources.

\section{Council renewal and the young people}

A cursory glance at the events of the 1960's suffices to show the strong cultural changes at work. The Church was engaged by the Second Vatican Council to renew herself ${ }^{1}$ and Pope John XXIII's opening address (10.11.1962) is clear:

what is needed is that this doctrine be more fully and more profoundly known and that minds be more fully imbued and formed by it. What is needed is that this certain and unchangeable doctrine, to which loyal submission is due, be investigated and presented in the way demanded by our times. For the deposit of faith, the truths contained in our venerable doctrine, are one thing; the fashion in which they are expressed, but with the same meaning and the same judgement, is another thing.

So the challenge was to say the same things in a new way. Over the following years the ecclesial dialogue with the contemporary world grew more and more. It is well described by Paul VI's encyclical Ecclesiam suam (6.08.1964). Also Karol Wojtyla-then Archbishop of Cracow-was engaged in the task, especially through his participation in the debate about the conciliar constitution Gaudium et spes. Paul VI deals with the same subject within his closing speech (7.12.1965). He says:

the teaching authority of the Church, even though not wishing to issue extraordinary dogmatic pronouncements, has made thoroughly known

1 Cf. G. Alberigo, A Brief History of Vatican II, New York 2006; J.W. O’Malley, What happened at Vatican II, Cambridge 2010; M. Faggioli, A. Melloni, Vatican II: The Complete History, Mahwah 2015. 
its authoritative teaching on a number of questions which today weigh upon man's conscience and activity, descending, so to speak, into a dialogue with him, but ever preserving its own authority and force; it has spoken with the accommodating friendly voice of pastoral charity; its desire has been to be heard and understood by everyone; it has not merely concentrated on intellectual understanding but has also sought to express itself in simple, up-to-date, conversational style, derived from actual experience and a cordial approach which make it more vital, attractive and persuasive; it has spoken to modern man as he is.

Young people were addressed by the Church as special interlocutors and this is why the Council Fathers sent a Message to them (8.12.1965):

The Church is anxious that this society that you are going to build up should respect the dignity, the liberty and the rights of individuals. These individuals are you. The Church is particularly anxious that this society should allow free expansion to her treasure ever ancient and ever new, namely faith, and that your souls may be able to bask freely in its helpful light. She has confidence that you will find such strength and such joy that you will not be tempted, as were some of your elders, to yield to the seductions of egoistic or hedonistic philosophies or to those of despair and annihilation, and that in the face of atheism, a phenomenon of lassitude and old age, you will know how to affirm your faith in life and in what gives meaning to life, that is to say, the certitude of the existence of a just and good God.

Today we face the same challenge: to make young people meet Christ and the Catholic faith as the answer to the deep questions concerning youth and life.

\section{Why did the "Sixties Protests" cause young people \\ in Western countries to abandon faith?}

Over the following years, the "Sixties Protests", often referred to as "counterculture movement" and diverted many young people from the faith. ${ }^{2}$ Why did this transpire? This is far from easy to answer, but

2 See A. Marwick, Cultural Revolution in Britain, France, Italy and the United States, Oxford 1998; M. DeKoven, The Sixties and the Emergence of the Post-Modern, Durham 2004; I. Morgan, From Sit-Ins to SNCC: T1 he Student Civil Rights Movement in the 1960s, Gainesville 2012; J. Willis, 1960s Counterculture, Santa Barbara 2015. 
it is clear that the big difference concerns the renewal as it was interpreted by the "Sixties Protests" and the Council. While the "Sixties Protests" were ideological, the Council was dialogical. The "ideological masters" were against tradition, they wanted to characterize every institution as abusive, practicing a self-referential attitude which radically opposed past and present. In contrast, the Catholic attitude comes from the faith in Jesus which has passed through the Church over the centuries. From this point of view past and present are within the same life, the living experience of the Church, living as the body described by Saint Paul (1 Corinthians 12:12-31). This is why the ecclesial mind is in favor of the composition rather than the opposition between tradition and the present, like the scribe "instructed in the kingdom of heaven" who "brings from his storeroom both the new and the old" (Matthew 13:52).

We can understand what happened during the post-Council years from an important speech by Pope Benedict XVI to the Roman Curia (22.12.2005):

The problems (...) arose from the fact that two contrary hermeneutics came face to face and quarrelled with each other. One caused confusion, the other, silently but more and more visibly, bore and is bearing fruit. On the one hand, there is an interpretation that I would call "a hermeneutic of discontinuity and rupture"; it has frequently availed itself of the sympathies of the mass media, and also one trend of modern theology. On the other, there is the "hermeneutic of reform", of renewal in the continuity of the one subject-Church which the Lord has given to us. She is a subject which increases in time and develops, yet always remaining the same, the one subject of the journeying People of God.

The Archbishop of Cracow, Karol Wojtyla, spoke in the same way in his book U podstaw odnowy, studium o realizacji Vaticanum II (Cracow 1972). For example, as a comment to the Credo by Pope Paul VI, he writes that it "clearly indicates that the teaching of Vatican II (...) must be organically inserted into the whole deposit of faith, so as to be integrated with the teaching of all preceding Councils and pontiffs." Twenty years after the end of the Council, Pope John Paul II, at the beginning of the Synod of Bishops about the reception of the Council, told the young people assembled in Saint Peter Square (24.11.1985):

3 K. Wojtyla, Sources of Renerwal: The Implementation of Vatican II, New York 1980, p. 19. 
Beloved young people, I am pleased by your presence in this important moment for the life of the Church. We are called to live again the extraordinary moment of grace which was the Second Vatican Council, to rediscover the richness of the truth contained in its documents, to think again the pastoral guidelines then chosen under the guidance of the Spirit. In this task the Church cannot act without you, young people, who are the future and bring in yourselves the hopes of the Church. Beloved young people, be at the side of the Synod Fathers with your prayers and take in your hands again the documents of the Council, be familiar to them, by them feed your spirituality. In the texts of the Council, you can certainly listen to what the Spirit teaches to the Church also today. Young people, the Council is twenty years old as you! The Council is young! Make it your own and give notice of it all over the world!.

These words are as full of affection as those said by Pope John Paul II to young people on many other occasions. ${ }^{4}$ He had faith in them and he expected good fruit to stem from youth actions as he said in his homily given at the World Youth Day 2000 (20.08.2000):

Thank God for the World Youth Days! Thanks be to God for all the young people who have been involved in them in the past sixteen years! Many of them are now adults who continue to live their faith in their homes and work-places. I am sure, dear friends, that you too will be as good as those who preceded you. You will carry the proclamation of Christ into the new millennium. When you return home, do not grow lax. Reinforce and deepen your bond with the Christian communities to which you belong. From Rome, from the City of Peter and Paul, the Pope follows you with affection and, paraphrasing Saint Catherine of Siena's words, reminds you: "If you are what you should be, you will set the whole world ablaze!". I look with confidence to this new humanity which you are now helping to prepare. I look to this Church which in every age is made youthful by the Spirit of Christ and today is made happy by your intentions and commitment.

Pope John Paul II had a predilection for working with young people, but he also knew the dangers of youth because this age is characterized by a carelessness and tendency to make moral mistakes. In fact, within his apostolic letter Dilecti amici (31.03.1985), addressed to the young people during the International Youth Year, he commented on the evangelical episode concerning the meeting between Jesus and the "young rich man". He didn't just commend the youth,

4 See M. Sebanc, Pope John Paul II: Education and Youth, Toronto 1984; P. Mitchell, John Paul, We Love You, Cincinnati 2007; K. Wojtyla, My Dear Young Friends, Winona 2011. 
but took into consideration that when we are young we can unfortunately move away from Christ too. He says there precisely:

We must ask the question: does this treasure of youth necessarily alienate man from Christ? The Evangelist certainly does not say this: rather, an examination of the text leads us to a different conclusion. The decision to go away from Christ was definitively influenced only by external riches, what the young man possessed ("possessions"). Not by what he was! What he was as precisely a young man - the interior treasure hidden in youthhad led him to Jesus. And it had also impelled him to ask those questions which in the clearest way concern the plan for the whole of life.

This is the crux of the matter-the extraordinary psycho-physical energy of young people is at risk of not being recognized as having a proper spiritual root. It transpires not only because young people can divert their attention, but also because they can be distracted by those who want to use their youthful energies to make money or to gain power. This is exactly what happened during the "Sixties Protests": the "bad masters" seduced young people and corrupted their desire of love and happiness into a mere search for pleasure. That attitude is clearly testified by the controversy concerning the encyclical Humanae vitae published in 1968. Pope Paul VI aimed to show the human meaning of love and sexuality, but his critics mistook liberty for liberties. It was a cultural turning point but one that reeked of egoism and demagogy. For this reason John Paul II, within Familiaris consortio (22.11.1981), says that the encyclical Humanae vitae is "a truly prophetic proclamation" (no. 29). About what? The human dignity of each one "as a person and as a child of God" (no. 64). More recently Pope Francis said: "We need to return to the message of the encyclical Humanae vitae of Blessed Pope Paul VI, which highlights the need to respect the dignity of the person" (no. 82).

In ancient times a "free citizen" was recognized because he was a "son of...": this is why today many surnames end with the proclitic "son". For the same reason in Latin the adjective ingenuus means "free" as "included in the gens (family)" and the same is true in Ancient Greek with the word ghennaios related to ghénos, "family". However, as I argued, because of the Sixties' "Protests" liberty was misinterpreted as license; in other words: it became common to think that to be free means only to choose among options. Actually it is wrong because to choose the worst means to become worse: we are 
free only to choose the best. How are we to recognize it? We must remember who we are and this is explained by the ancient reference to the family. The ancient mind was aristocratic (only few people were recognized as free), whilst today's mentality is democratic (every person has rights), but demagogy - relativistic and permissive-is the opposite of democracy. In fact, to be responsible means to act in a responsive way which corresponds to human dignity.

Affectivity and sexuality are only apparently the same to animals and mankind because they express something deep within the human identity. For example, we can understand it, if we consider the part of the Song of Songs where the relationship between two lovers is the symbol of the relationship between God and the "elect": Saint Paul confirms the deep meaning of human love when he compares it to Jesus' love of the Church (Ephesians 5:32). So given the situation, there is absolutely nothing surprising in the tension between Catholic education and the common mentality - youth behavior included — under the influence of demagogical and lax ideas. But it is also clear that the heart of the challenge is to give the right meaning to human freedom and this is the great opportunity for Catholic education.

\section{How to make young people aware of true freedom?}

Previously I emphasized that freedom has been misunderstood and I said that the crisis within the relationship between young people and faith is related to that situation. I also identified the turning point in the publication of Humanae vitae because of the rejection of the papal document. In fact, one of the subjects under discussion was the body: one of the fundamental issues within anthropology. Since the end of the Sixties the common trend has been to consider the body as an object for one's own use: consequently human sexuality became arbitrary. The problem is that, the more the custom became common, the more that human identity ended in reification. Yet the human being is a subject, not an object as Thomas Aquinas ("Doctor Communis" within Catholic theology) and Immanuel Kant (the modern, secular philosopher par excellence) say. I believe that the point is crucial and needs to be explored further.

Starting from the "Sixties Protests", human freedom incurred three misunderstandings which whilst not totally wrong are if they 
are considered in their absolute form. The first was to interpret liberty as spontaneity. It happened by coherence to anti-institutional tendencies against norms, rules, in a word: the "father". Actually it lasted for a short time because it was clear that spontaneity, by itself, does not allow human behavior to be distinguished from the animal. Anyway it was clear that freedom was the "core question", so it started the second tendency: to identify liberty as the possibility to choose among alternatives. This time the problem is that if someone chooses the wrong possibility (not deserving human dignity), he/she becomes worse. Aristotle distinguishes between poietic acts and practical acts, by observing that-in the first case- the human action becomes an object while - in the second case - the agent becomes better or worse according to his/her action. We must remember that freedom is a means not an end, because it aims to improve a human being's ethical maturity: for this reason we are free only if we choose what is good. Recently a new tendency arose to consider liberty as self-determination. There is something true in this idea, but the problem is that nobody chose to be born. What does it mean? If self-determination is the condition to be considered free, how is it possible to recognize freedom as peculiar to humans? Actually everyone was called to life with no involvement on their part. Naturally self-determination is a feature within the human liberty, but it isn't enough: it is necessary to recognize the criterion in order to choose only the best: it is the dignity proper to each human being considered as an end in him/herself.

A famous tale can help to focus the issue: the parable of the "prodigal son" (Luke 15:11-32). This concerns a young man who took his inheritance from his father and ran away to spend it. He began to live spontaneously, he gratified all his whims, he chose arbitrarily and practiced self-determination looking only for what gave him pleasure. Finally he was penniless. Then, he "came to his senses" and thought: "How many of my father's hired workers have more than enough food to eat, but here am I, dying from hunger. I shall get up and go to my father and I shall say to him, «Father, I have sinned against heaven and against you. I no longer deserve to be called your son; treat me as you would treat one of your hired workers»." So he did, but his father gave him a welcome worthy of his dearest son. What made the young man think about his own condition? Not only to be without money. He "came to his senses" because "he longed to 
feed himself with the pods eaten by the swine": he understood that he aimed at was below his dignity. Freedom-as I said before-is not an end but a means: to go below the human dignity means not to be free even if it's the consequence of one's choice. The evangelical parable supplies us with the key-idea to open up today's situation. The consumerist society attracts not only young people but all of us because it allows us to have pleasures and a good time. The point is that we are encouraged to become consumers of everything more and more, even our feelings, our bodies and our lives. This is the problem: finally — as the "prodigal son"-we lose our self-respect. In Western countries a living proof of the problem is loneliness as the consequence of living under the rule of the self-centredness. This is why freedom must be set free.

In the Old Testament God is the liberator par excellence, in the New Testament Jesus is the "redeemer" because he makes free. His message is that we are "children of God" by adoption (Romans 8:14). Here is the Christian "good novel" of liberation: the truth that makes us free (John 8:32). For this reason we must point upwards and not surrender to the consumer habits that make us not live as people endowed with dignity. What John Paul II said to the Dutch youth on 14.05.1985 is relevant today too:

Dear friends, let me be very clear. I know that you speak in all good faith. But are you really sure that your idea about Christ fully correspond to him? The Gospel, in fact, testifies a very demanding Christ, asking the radical conversion of the heart (Mark 1:5), to leave the goods of the earth (Matthew 6:19-21), to forgive offenses (Matthew 6:1415), to love enemies (Matthew 5:44), to tolerate oppressions (Matthew 5:39-40), and even to sacrifice ourselves for love (John 15:13). In particular, with regard to the sexual life, it's clear Jesus' strong teaching in favor of the indissolubility of marriage (Matthew 19:3-9), against the simple adultery of the heart (Matthew 5:27-28). And how is one not to be shocked by the command to "extricate the eye" or to "cut the hand" if they give "scandal" (Matthew 5:29-30)? In front of these evangelical references, is it realistic to imagine a "permissive" Christ about marriage, abortion, premarital, extramarital or homosexual sex? The first Christian community, guided by those who had personally known the Christ wasn't permissive at all-it is enough to mention the Pauline letters about this matter (Romans 1:26; 1 Corinthians 6:9; Galatians 5,19). The Apostle's words are unquestionable and inspired from above and they are normative for the Church today too. (...) The human being matters! In ecclesial teachings the Church never pro- 
nounces judgments on the sinners, but always on the sins. It is necessary to recognize the difference between the good and the evil. To be permissive does not make people to be happy. Likewise, the consumer society does not give the joy to the heart. The human being achieves the proper aims only being able to accept what is demanded from the human dignity related to be "God's image" (Genesis 1:27).

It is clear the call to Christian education is the way to become aware of human dignity.

\section{How to encourage young people to make themselves free?}

Nothing about being young makes us disposed to think of the future. That's why it is the "project age" par excellence, based on the psycho-physical-moral energies coming from youth. To be young always means to be involved within enterprises and dreams, but also to be at risk because many energies are also many possibilities to waste time, money and opportunities. Besides, the task of maturity can be confused with the aim of being functionally effectual, but this isn't the right way to do projects about the future because youth is a call to magnanimity too. ${ }^{5}$

This issue is good to recognize today's youth-theft. In fact, young people are constantly hit by messages directed to make them uncertain about their future. Primarily this concerns their employment opportunities: in Italy (as well as abroad, Poland inclusive), young people know that they must study for many years to attain uncertain and precarious jobs. It also happens within the affective field:

5 About today's youth situation see: P. Vogel, Generation Jobless?, London 2015; R.D. Putnam, Our Kids: The American Dream In Crisis, New York 2015. About young people and faith see as biographical approach: A. Flannagan, A. Calver, 12 Disciples: Young People's Stories of Crisis and Faith, London 2007; as critical approach: D. Kinnaman, G. Lyons, G. Barna, unChristian: What a New Generation Really Thinks About Christianity, Grand Rapids 2007; R. Wuthnow, After the Baby-Boomers: How Twenty-And Thirty-Somethings Are Shaping the Future of American Religion, Princeton 2007; C. Smith, P. Snell, Souls In Transition: The Religious and Spiritual Lives of Emerging Adults, Oxford 2009; K.C. Dean, Almost Christian: What the Faith of Our Teenagers Is Telling the American Church, Oxford 2010; D. Kinnaman, A. Hawkins, You Lost Me: Why Young Christians Are Leaving Church... and Rethinking Faith, Grand Rapids 2011; T.S. Rainer, J.W. Rainer, The Millennials, Nashville 2013. 
in my country half of all marriages end in separation or divorce, and young people prefer cohabitation to the marriage. In short, young people are at risk of not having faith in their future and surrendering to the current situation. This attitude is very dangerous because the lack of a future directly threatens the present day. The reason is well described by an ancient doctrine. According to it the action is unified by its end-here the existential translation: the future guards today's actions. What does it mean? If someone doesn't look at the future, he/she lives the present with no care of him/herself. Obviously this happens at all ages, but it is especially dangerous in our youth years because of the strong energies peculiar to young people. We have evidence of it if we consider the so called "youth discomfort" regarding bad conduct-drug use, alcohol abuse, eating disorders, violence-within the most schooled generation in history, well informed, with health high levels and free to do all they want... How to explain facts like these? How to explain this self-destructive way of life? Perhaps by the "lack of future": if the young boy or girl has no faith in his/her future, he/she is under the attraction of what now he/she is interested in - without any attention to dangers-I want to be clear: I would not claim that all young people or many young people live in this way even if they are few, they are actually too many because of the intrinsic value of each human being, especially when he/she is young. We must recall the great concern of the great saints towards young people. For example, Don Bosco:

My dear friends, I love you with all my heart, and it is enough that you are young for me to love you very much. I can assure you, you will find books written for you by persons much more virtuous and clever than I, but you will struggle to find anyone who loves you in Jesus Christ more than I do, or who wants to see you truly happy more than I do. ${ }^{6}$

He speaks in this way because of his Christian faith: young people are the dearest to the Lord. We can start from this evidence in order to make them meet Jesus.

\footnotetext{
6 Don Bosco, The Companion of Youth (1847), Preface.
} 


\section{The Christian faith as a gift to young people, young people as a gift to the Church}

Faith is God's gift, it is a gift to everyone, but especially to young people. When, in the Bible, God addresses to his elect, He says: "I took you by the hand" (Isaiah 42:6), as a father does with his son. He takes great care of young people as it is clear-for examplewhen God chooses David as king of Israel. He sends the prophet Samuel to David's father-Jesse-in order to anoint the new king. Jesse presents the males of his family to Samuel starting from the most grown-up (considered the strongest), but God chooses the youngest (1 Samuel 16:1-13). In another tale, we know Jeremiah's objection to the divine vocation and God's answer: "Don't say 'I am too young'. To whomever I send you, you shall go; whatever I command you, you shall speak. Have no fear before them, because I am with you to deliver you" (Jeremiah 1:7-8). In particular, Christ has predilection for the children ("unless you turn and become like children, you will not enter the kingdom of heaven": Matthew 18:3), and reserves to the young people his specific attention as when he resurrected the widow's son (Luke 7:11-17). Where is the root of the proximity between Christian faith and youth?

The Christian God is "the one who is and who was and who is to come" (Revelation 1:8). These words are similar to what the "burning bush" says to Moses: "I am who I am" (Exodus 3:14). It is not a static identity but a dynamic one: the biblical God is the Leader of human history, starting from the creation of the world. He leads the "elected people" to the "promised land" through Moses and sent his Son to redeem (to re-create) the world. Since the beginning of biblical story, He is described as active. New Testament faith makes it more evident by speaking of God as the Trinity: the Holy Spirit identifies the divine Person perpetually acting within history. In particular, the Church Fathers interpreted the divine action as educational. Especially Clement of Alexandria talks about the issue within his book The Pedagogue. Both he and Origen emphasize that God's educational action is free (being inspired only by love) and directed to the free human creature.

Among the evangelists, John says clearly that God doesn't consider us as slaves, but as friends (John 15:15). According to the tradition, 
John was the youngest among the apostles and the beloved by Jesus. He asserts one of the strongest statements within the New Testament: "God is love" (1 John 4:8). But love is the "core" young desire! That's why Jesus-God's Son-is close to young people. Naturally it is necessary not to misunderstand what love is. Human love has great value, that's why it is wrong to bring it to compulsive/compensatory actions, subdued to utility: it is worth care. Pauline epistolary helps to understand: 'Everything is lawful for me'. But not everything is beneficial. 'Everything is lawful for me'. But I will not let myself be dominated by anything" (1 Corinthians 6:12). The permissive trends make everything allowed, but Saint Paul reminds us that we can become worse by our actions. In fact, the challenge is not to be dominated by instincts and pleasures - like the "prodigal son"-in order to choose only what we deserve, up to our dignity of God's sons.

As I told before, the point is liberty. In the Letter to the Diocese of Rome about the urgent issue of education (21.01.2008) Benedict XVI says:

Dear brothers and sisters of Rome, at this point I would like to say some very simple words to you: Do not be afraid! In fact, none of these difficulties is insurmountable. They are, as it were, the other side of the coin of that great and precious gift which is our freedom, with the responsibility that rightly goes with it. As opposed to what happens in the technical or financial fields, where today's advances can be added to those of the past, no similar accumulation is possible in the area of people's formation and moral growth, because the person's freedom is ever new. As a result, each person and each generation must make his own decision anew, alone. Not even the greatest values of the past can be simply inherited; they must be claimed by us and renewed through an often anguishing personal option.

Some years later, Pope Francis repeated the same ideas when speaking to Jesuit students (7.06.2013):

the main element at school is to learn to be magnanimous. Magnanimity: this virtue of the great and the small (...), which always makes us look at the horizon. What does being magnanimous mean? It means having a great heart, having greatness of mind; it means having great ideals, the wish to do great things to respond to what God asks of us. Hence also, for this very reason, to do well the routine things of every day and all the daily actions, tasks, meetings with people; doing the little everyday things with a great heart open to God and to others. It is therefore important to cultivate human formation with a view to magnanimity. (...) 
First of all: be free people! What do I mean? Perhaps it is thought that freedom means doing everything one likes, or seeing how far one can go by trying drunkenness and overcoming boredom. This is not freedom. Freedom means being able to think about what we do, being able to assess what is good and what is bad, these are the types of conduct that lead to development; it means always opting for the good.

Also Pope Francis reminds us that freedom is a means not an end: for this reason it needs the criterion to act well. Once again, the basic criterion is the dignity of human beings. The Jewish faith testifies that God is interested in human destiny, for this reason-in Genesis-He takes care of Adam and Eve after the "original sin". He forms alliances with Noah and Abraham in order to save all of humanity, but the pinnacle of God's care towards mankind is Christ because nothing comparable with his sacrifice could ever transpire. God sent His only Son in order to save all humanity and make everyone aware of filial dignity. From the cultural point of view, there were essential consequences, as it is proved by the gradual overcoming of slavery, practiced everywhere within ancient societies. The new social-political trend originated from Christian Revelation and its idea of never-ending human dignity because of God's never-ending love to each man/woman. Saint Paul clearly says:

What will separate us from the love of Christ? Will anguish, or distress, or persecution, or famine, or nakedness, or peril, or the sword? (...) No, in all these things we conquer overwhelmingly through him who loved us. For I am convinced that neither death, nor life, nor angels, nor principalities, nor present things, nor future things, nor powers, nor height, nor depth, nor any other creature will be able to separate us from the love of God in Christ Jesus our Lord (Romans 8:35-39).

The Christian faith made a fundamental contribution to the recognition of personal dignity and that is why it is essential in order to recognize the full meaning of human freedom. To believe in Jesus and to join the Church is essential also as regards the future. From this point of view, we must not forget that we believe in the "God of the promise", the "God of the alliance", for this reason the "God of the future". To introduce the young people into the faith means to make them to meet God as the One who called them to life. Within Catholic education this doctrine is related to the concept of "vocation". It is the key-concept in the Christian way of life. 
Today we have a positive tendency to organize and plan and it is good not to improvise, but we must not forget that our programs are always relative and, even when they take inspiration from the scientific data, it is necessary to give priority to wisdom as a peculiar knowledge. I don't want to reject the scientific-descriptive approach from the pedagogical point of view, but to subordinate it to the originality of Christian education coming from the personal encounter with Jesus through the Church. Once again we receive help from the Fathers of the Church when, facing the pagan prejudice about the faith as second-class knowledge (as Plato considers it when he classifies different types of knowledge), argue the essentiality of faith. Even in a simple way (for example, Arnobius ${ }^{7}$ underlines that-when someone starts on a journey-he/she trusts that they will reach the destination), they show that it is imperative to believe, not only to know. It is necessary to join together faith and anthropology because faith and freedom are strictly connected. In fact they are both human peculiarities and for this reason essential to human life. This is why it is necessary to promote Christian education among young people: they deserve to be free and open to the future.

\section{BIBLIOGRAPHY}

Alberigo G., A brief history of Vatican II, Orbis Books, New York 2006.

Arnobius, Adversus nationes, in: C. Marchesi, Arnobii adversus nationes libri vii (Corpus Scriptorum Latinorum Paravianum), Turin 1953.

Dean K.C., Almost Christian: What the Faith of Our Teenagers Is Telling the American Church, Oxford University Press, Oxford 2010.

DeKoven M., The Sixties and the Emergence of the Post-Modern, Duke University Press, Durham 2004.

Don Bosco, The Companion of Youth (1847), Preface.

Faggioli A., Melloni M., Vatican II: The Complete History, Paulist Press, Mahwah 2015.

Flannagan A., Calver A., 12 Disciples: Young People's Stories of Crisis and Faith, Monarch Publications, London 2007.

Kinnaman D., Hawkins A., You Lost Me: Why Young Christians Are Leaving Church... and Rethinking Faith, Baker Books, Grand Rapids 2011.

Kinnaman D., Lyons G., Barna G., unChristian: What a New Generation Really Thinks About Christianity, Baker Books, Grand Rapids 2007.

7 See Arnobius, Adversus nationes, II, 8. 
Marwick A., Cultural Revolution in Britain, France, Italy and the United States, Oxford University Press, Oxford 1998.

Mitchell P., John Paul, We Love You, Franciscan Media, Cincinnati 2007.

Morgan I., From Sit-Ins to SNCC: The Student Civil Rights Movement in the 1960s, University Press of Florida, Gainesville 2012.

O'Malley J.W., What Happened at Vatican II, Harvard University Press, Cambridge (MA) 2010.

Putnam R.D., Our Kids: The American Dream In Crisis, Simon \& Schuster, New York 2015.

Rainer T.S., Rainer J.W., The Millennials, B\&H Publishing Group, Nashville 2013.

Sebanc M., Pope John Paul II: Education and Youth, Metropolitan Separate School Board, Toronto 1984.

Smith C., Snell P., Souls in Transition: The Religious and Spiritual Lives of Emerging Adults, Oxford University Press, Oxford 2009.

Vogel P., Generation Jobless?, Palgrave Macmillan, London 2015.

Willis J., 1960s Counterculture, ABC-CLIO, Santa Barbara 2015.

Wojtyla K., My Dear Young Friends, Saint Mary's Press, Winona 2011.

Wojtyla K., Sources of Renewal: The Implementation of Vatican II, Harper and Row, New York 1980.

Wuthnow R., After the Baby-Boomers: How Twenty- and Thirty-Somethings Are Shaping the Future of American Religion, Princeton University Press, Princeton 2007.

\section{ADDRESS FOR CORRESPONDENCE:}

Prof. Giuseppe Mari

Catholic University of Sacred Heart, Milan, Italy

giuseppe.mari@unicatt.it 